\title{
Danièle DEHOUVE, Anne-Marie VIÉ-WOHRER, Le monde des Aztèques
}

Paris, Riveneuve Éditions, 2008, 335 p.

\section{Evan Mirzayantz}

\section{CpenEdition}

Journals

Édition électronique

URL : http://journals.openedition.org/assr/21554

DOI : $10.4000 /$ assr.21554

ISSN : $1777-5825$

Éditeur

Éditions de l'EHESS

Édition imprimée

Date de publication : 31 décembre 2009

Pagination : $75-342$

ISBN : 978-2-7132-2218-4

ISSN : 0335-5985

\section{Référence électronique}

Evan Mirzayantz, «Danièle denouve, Anne-Marie vié-wohrer, Le monde des Aztèques », Archives de sciences sociales des religions [En ligne], 148 | octobre-décembre 2009, document 148-41, mis en ligne le 27 janvier 2010, consulté le 24 septembre 2020. URL : http://journals.openedition.org/assr/21554 DOI : https://doi.org/10.4000/assr.21554

Ce document a été généré automatiquement le 24 septembre 2020.

(C) Archives de sciences sociales des religions 


\section{Danièle DEHOUVE, Anne-Marie VIÉ- WOHRER, Le monde des Aztèques}

Paris, Riveneuve Éditions, 2008, 335 p.

\section{Evan Mirzayantz}

\section{RÉFÉRENCE}

Danièle DEHOUVE, Anne-Marie VIÉ-WOHRER, Le monde des Aztèques, Paris, Riveneuve Éditions, 2008, 335 p. 